\title{
Left Dislocation and its translation in some Germanic languages
}

\author{
Christo H. J. van der Merwe \\ Department of Ancient Studies, University of Stellenbosch, South Africa. \\ E-mail: cvdm@sun.ac.za
}

\begin{abstract}
In terms of the theoretical framework of an influential recent model of Bible translation, Left Dislocation (=LD) can be regarded as a "communicate clue" that translators must try to interpretively resemble in their target text translation. This exploratory study investigates how twenty translations (fifteen English, three Afrikaans, one German, and one Dutch) have interpretively resembled (or not) nine prototypical constructions, and one less prototypical one, from the book of Genesis. It has been found that, firstly, translations on the formal equivalent pole tend to interpretively resemble LD constructions. If the LD tends to be very prototypical, this tendency is displayed even by some translations towards the functional equivalent pole. Secondly, even in the case of prototypical instances, translations on the functional equivalent pole, however, tend not to interpretively resemble the construction. In these cases, it could be argued that they are not serving the very goal that they as a rule want to accomplish-that is, to provide readers with a translation that is easy to read and process. Thirdly, the structure of English, Afrikaans and Dutch-in contrast to German-often appears to require a construal that does not formally reflect the pronominal resumption of the LD constituent in the matrix clause. Fronting the LD constituent is often used, and sometimes a pause after the fronted (i.e. then dislocated) constituent is signaled by means of a comma or a dash. These findings concur with those of some of the other papers in this volume. Resumption, for example, is not always the primary distinctive feature of a LD construction; a tonal pause between the LD and its matrix clause may also suffice. There are also historical explanations as to why some of the functions of fronting and LD constructions overlap.
\end{abstract}

Keywords: Left Dislocation, Information Structure, Translation Theory, Bible Translation, Biblical Hebrew

\section{Introduction ${ }^{1}$}

Throughout the ages it has been a challenge for translators of the Bible to prepare translations that are both faithful to the sourcez text and understandable. This challenge has been addressed

\footnotetext{
${ }^{1}$ This work is based on research supported in part by the National Research Foundation of South Africa (Christo H. J. van der Merwe UID 85432). The grantholder acknowledges that opinions, findings and conclusions or recommendations expressed in any publication generated by the NRF supported research are those of the author, and that the NRF accepts no liability whatsoever in this regard.
} 
in a variety of ways; compare, for example, the history of the LXX, Targums and the Vulgate (Metzger 2001: 13-24, 29-35). Since the 16th century, faithfulness became associated with a word for word, or what could be regarded as a type of formal equivalence to the source text a perception that may go back to Aquila (Metger 2001: 19). In the 20th century, this situation drastically changed. One the one hand, more and more readers of the Bible insist on Bibles that they can understand. On the other hand, insights into how language and communication works exposed the extent to which word for word translations are prone to be misunderstood. ${ }^{2}$

A quest for Bible translations that are more understandable, but still faithful to the source text, posed new challenges for the notion of “equivalence”. Nida's models of dynamic ${ }^{3}$ and later, functional equivalence, ${ }^{4}$ represent attempts to address these challenges in terms of the linguistics and communication models of his day. Nida, with a background in linguistics and anthropology was well aware of the complexities involved in translating ancient sacral text. For example, the challenges posed by the incongruences between the conceptual world of the source text, the translator, and the target text. He nevertheless believed that what could be said in language A could also be said in language B. In other words, translation is replacing one set of codes with another one.

Nida's work has made a lasting impact on the field of translation. ${ }^{5}$ However, developments during the last quarter of the 20th century in translation studies and linguistics exposed the shortcoming of some of his linguistics assumptions. ${ }^{6}$ In the field of Translation Studies the notion of equivalence at large has been challenged. So much so that most Translation Studies scholars regard any attempt to attain equivalence whether at word, sense, text or functional level between a source and target text as a futile exercise. According to Pym (2010:41) there are only "a handful of theories that emphasizes the social function of equivalence as a shared illusion, a social function that becomes cost-effective in the practices of cross-cultural communication". The focus of Translation Studies shifted to that of identifying by means of descriptive studies all the "frames" or considerations that come into play in the process of translation as transcultural communication, e.g. textual, physical, cultural, sociological, historical, ideological, organizational, etc. ${ }^{7}$

This so-called cultural turn in Translation Studies coincides with developments in linguistics. Although at the beginning of the 20th century some linguists (e.g. Sapir and Whorf) had pointed out the embeddedness of language in culture, the primary focus of 20th century linguistics was on the form and structure of language as an abstract system - also meaning was studied as a decontextualized system of components, e.g. Nida's semantic model of componential analysis and the notion of lexical fields he worked with. ${ }^{8}$ This situation changed when linguists in the last quarter of the century became increasingly interested in how humans use language. This led, among others, to a fairly general consensus among scholars that the use of language entails much more than a set of codes. One of Nida's basic assumptions, namely that translation in

\footnotetext{
${ }^{2}$ See Van der Merwe (1999).

${ }^{3}$ See Nida and Taber (1969)

${ }^{4}$ See De Waard and Nida (1987).

${ }^{5}$ See Carson (1993)

${ }^{6}$ See, Mojola and Wendland (2003: 4-11).

${ }^{7}$ See Wilt (2003: 27-80).

${ }^{8}$ For an overview of structural semantics, cf. Geeraerts (2010: 47-97).
} 
essence entails the exchange of the set of codes of a source language with that of the target language, became impossible to maintain.

The study of the function and use of language was typically conducted in the circles of functional grammar, discourse analysis and pragmatics. Insights from these fields of study have been used in some models of translations to analyze a source text in order to determine possible equivalents in the target text. In the field of Bible translation, insights from Relevance Theory (a pragmatic theory), which adheres to an inferential model of communication, has been used by Gutt (1991 and 2000) to postulate a new model of Bible translation. According to Gutt, Bible translation is an extremely difficult instance of secondary communication. The challenge of this difficult form of communication could be addressed by means of either a "direct" or an "indirect" translation. Gutt uses these two notions in analogy to the notions "direct" and "indirect" speech. In a direct translation, which purports to "quote directly" the author of the source text, translators attempt to "interpretatively resemble" all the communicative clues of the source text in the context and conceptual world envisaged for the original audience of the source text. In "indirect translations," an attempt is also made to "interpretively resemble" the communicative clues of the source text, but in terms of the context and conceptual word of the target language culture. In contrast to Nida, Gutt did not adhere to the code model of communication. His inferential model of communication fully acknowledges that it is often not possible to interpretively resemble the full meaning of a word or expression by means of a translation equivalent. In those instances, the cognitive world of the target text readers needs to be supplemented by means of paratexts.

A key notion in Gutt's model is the notion "communicative clue". These clues need to be identified in the source text and be "interpretively resembled". In terms of Gutt's model, left dislocation can be regarded as an overt communicative clue.

\section{Problem}

Gutt's theoretical depiction of Bible translation cannot be faulted, and the heuristic value of the notion of "communicative clue" cannot be denied. Gutt succeeds in pointing out the complexities of translation as "interlingual interpretative use" and the complexity of the range of parameters to be considered in general. Gutt's notion of a direct translation is also showing its practical value in a major current translation of the Bible in Afrikaans. ${ }^{9}$ However, Gutt provides little insight into the principles according to which the meaning of linguistic constructions may develop, firstly across languages and secondly, in a particular language $\mathrm{x}$. For example, in the case of "communicative clues arising from semantic representations" with reference to Sperber and Wilson (1986), he (Gutt 2000:141-144) points out the need to distinguish between the logical and encyclopaedic components of a lexical entry, but gives no indication of how and when the bodily, physical, psychological, and cultural experiences of a language community may become entrenched as part of their linguistic code. ${ }^{10}$ It may be argued that Gutt, like many of the descriptive translation approaches of our day, has sensitized translators for the complexity of the task at hand, the co-textual, contextual, cultural, and sociohistorical considerations that have to be considered, but fall short of providing translators with some form of empirically grounded evidence or integrating framework for opting for a translation solution A instead of solutions B or C (in a context X of a source text that is

\footnotetext{
${ }^{9}$ Cf. Van der Merwe (2012 and 2014).

${ }^{10}$ Cf. Van der Merwe (2014) for reservations about some of Gutt’s “communicative clues”.
} 
translated for the purpose Y). As far as LD is concerned, one has to be fair towards Gutt - left dislocation primarily involves procedural meaning. In other words, the construction is used as a means to signal to the addressees how information about actors and/or entities should be processed. The construction typically does not encode any encyclopaedic information. Nevertheless, answers to the question as to how LD, as a symbolic unit, may develop, be used for, and acquire a variety of purposes - some prototypical and other less prototypical - in a specific language is as a rule beyond the scope of the truth-conditional semantics that relevance theory and Gutt adheres to. One of the main purposes of this project has been to get a clearer picture of how LD are used in different languages. A basic assumption is that language is a dynamic and complex system. This implies that, on the one hand, the same construction may have more than one function in language $\mathrm{X}$, and, on the other hand, the same function may also be expressed by more than one formal contruction in that same language $\mathrm{X}$ (cf. Andrason 2016a\&b). When one considers how LD are translated, one is therefore faced with the question: Did the translators fail to recognize or understand the functional value of the LD, or did their target language constrain the overt resemblance of the LD? Addressing these questions, is the focus of this paper.

\section{Goal and method}

This study investigates what Germanic (mainly English) translations have done with LD, an overt communicative clue that is attested across languages. The study has been prompted by the observation that the construction is apparently often ignored by translators. It is acknowledged, on the one hand, that the structure of languages differ and that in some languages attempts to formally resemble the LD in Biblical Hebrew may lead to ungrammatical and stylistic clumsy translations (cf. Andrason 2016b). It is also acknowledged that, on the other hand, the implicit or explicit translation brief of translations differ. However, it is hypothesized that (i) while formally equivalent translations typically attempt to "interpretively resemble" obvious prototypical instances of LD, they sometimes fail to adequately render less prototypical instances; (ii) translations towards the functional pole of the continuum, often appear to uncritically assume that any attempt to resemble the LD may give rise to translations that do not reading smoothly enough; ${ }^{11}$ and (iii), constructions that are often used to interpretively resemble LD constructions in Biblical Hebrew may point to distinctive features of LD constructions in those target languages that differ from that of Biblical Hebrew. The goal of this study is to test the above-mentioned hypotheses. In this way, the value of fully understanding the function(s) of LD constructions and the need for concerted efforts to interpretively resemble them in terms of the structural features available in the target language, in all types of translations, can be illustrated.

For the purposes of this exploratory study I have selected twenty different translations ranging from the "extreme" literal word for word version like the KJV to the more "moderate" NIV and $\mathrm{CEB}$, to the CEV and the Message that often boarder on paraphrases. The rendering of ten instances of LD by the above-mentioned translations are listed from what will be regarded as the formal equivalence pole (=FOE) of the continuum to that what is regarded as the functional equivalent pole (=FUE), viz., KJV (1900), NKJV (1979), DBV (forthcoming), Elberfelder (1985), NASB (1995), NRSV (1989), ESV (2001), NJPS (1985), NJB (1985), NIV (2011),

\footnotetext{
11 This is ironic, since attempts to interpretively resemble the LD's could have had enhanced what those translations in essence are supposed to do, viz. to be easily readable and understandable translations.
} 
CEB (2011), NBV (2004), ISV (2011), NET (2006), NLT (2013), NLV (2006), BNV (1983/1998), GNB (1992), CEV (1995) and The Message (2005).

Starting by what could be regarded as more prototypical instances of LD, the two hypotheses postulated above will be "tested" by means of the following questions that are posed to each example that have been investigated: Firstly, what is the function of the LD in terms of our theoretical model? Secondly, do the translations overtly interpretively resemble, or reflect an attempt to resemble the function of the LD? Thirdly, do the way in which the translations overtly reflect (or not reflect) the LDs correlate with their positions on the continuum between the two poles? Fourthly, can the neglect to interpretively resemble the LD and/or its resumption be explained by other considerations than not recognizing or appreciating the function of the LD construction?

\section{Examples}

\section{Example 1}

The referent of LD represents a switched topic that had been in need of reactivation, so that something can be said about them (cf. Westbury 2016). The use of LD eases the processing effort of the information, in the case of \#1 about "the donkeys that were lost three days ago" (referred to in 1 Sam 9:3), viz. "do not worry about them, for they have been found”.

(1) 1 Sam. 9:20 (uniquely identifiable)

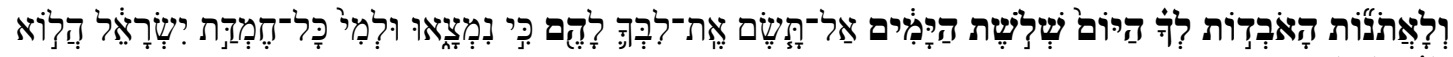

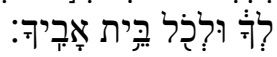

"As for your donkeys that were lost three days ago, give no further thought to them, for they have been found." (NRSV)

\begin{tabular}{|l|l|}
\hline KJV & $\begin{array}{l}\text { And as for thine asses that were lost three days ago, set not thy mind on } \\
\text { them; for they are found. }\end{array}$ \\
\hline NKJV & $\begin{array}{l}\text { But as for your donkeys that were lost three days ago, do not be anxious } \\
\text { about them, for they have been found. }\end{array}$ \\
\hline DBV & $\begin{array}{l}\text { Wat die donkiemerries betref waarna jy vandag drie dae lank al op soek is: } \\
\text { Moet jou nie oor hulle bekommerg nie, want hulle is gevind. }\end{array}$ \\
\hline Elberf. & $\begin{array}{l}\text { Und was die Eselinnen betriff, die dir heute vor drei Tagen } \\
\text { verlorengegangen sind, so brauchst du dir um sie keine Sorgen zu Machen, } \\
\text { denn sie sind gefunden. }\end{array}$ \\
\hline NASB & $\begin{array}{l}\text { As for your donkeys which were lost three days ago, do not set your mind on } \\
\text { them, for they have been found. }\end{array}$ \\
\hline
\end{tabular}




\begin{tabular}{|c|c|}
\hline ESV & $\begin{array}{l}\text { As for your donkeys that were lost three days ago, do not set your mind on } \\
\text { them, for they have been found. }\end{array}$ \\
\hline NJPS & $\begin{array}{l}\text { As for your asses that strayed three days ago, do not concern yourself about } \\
\text { them, for they have been found. }\end{array}$ \\
\hline NJB & $\begin{array}{l}\text { As regards your donkeys, however, which strayed three days ago, do not } \\
\text { worry about them; they have been found. }\end{array}$ \\
\hline NIV & $\begin{array}{l}\text { As for the donkeys you lost three days ago, do not worry about them; they } \\
\text { have been found. }\end{array}$ \\
\hline CEB & $\begin{array}{l}\text { As for the donkeys you lost three days ago, don't be worried about them } \\
\text { because they've been found. }\end{array}$ \\
\hline NBV & $\begin{array}{l}\text { En wat betreft die ezelinnen die nu al drie dagen zoek zijn: maakt u zich geen } \\
\text { zorgen, die zijn terecht. }\end{array}$ \\
\hline ISV & $\begin{array}{l}\text { Now as for your donkeys that were lost three days ago, don't give any } \\
\text { thought to them, because they've been found. }\end{array}$ \\
\hline NET & $\begin{array}{l}\text { Don't be concerned about the donkeys that you lost three days ago, for they } \\
\text { have been found. }\end{array}$ \\
\hline NLB & $\begin{array}{l}\text { And don't worry about those donkeys that were lost three days ago, for they } \\
\text { have been found. }\end{array}$ \\
\hline NLV & $\begin{array}{l}\text { En moet jou nie meer bekommer oor jou pa se donkies wat drie dae gelede } \\
\text { weggeraak het nie. }\end{array}$ \\
\hline BNV & $\begin{array}{l}\text { Jou donkies is vandag al drie dae weg. Jy moet jou egter nie oor hulle } \\
\text { bekommer nie, want hulle is gekry. }\end{array}$ \\
\hline GNB & $\begin{array}{l}\text { As for the donkeys that were lost three days ago, don't worry about them; } \\
\text { they have already been found. }\end{array}$ \\
\hline CEV & $\begin{array}{l}\text { Don't worry about your donkeys that ran off three days ago. They've already } \\
\text { been found. }\end{array}$ \\
\hline Message & $\begin{array}{l}\text { And by the way, your lost donkeys—the ones you've been hunting for the last } \\
\text { three days-have been found. }\end{array}$ \\
\hline
\end{tabular}

Most translations, i.e. 14/20, interpretively resemble this LD. Although most translations towards the FUE pole (NET, NLB, NLV, BNV and CEV) appear not to try to overtly resemble the LD. ${ }^{12}$ However, this is not true of all of them, compare the GNB and The Message. It is

${ }^{12}$ The "those donkeys" of the NLB might be regarded as an attempt to reflect a trace of the LD. 
reasonable to infer from this evidence that it is possible to render the LD in idiomatic good English and in this way enhance the processing of the translated text for its target audience. It may also be argued that a failure to do so, ironically undermines one of the primary goals of these translations, viz. to enhance the processing of the translation for its target audience. ${ }^{13}$

\section{Example 2}

In this case, the Israelites are provided some regulations about the tithes they have to bring to the temple and how they should perform this task. After giving instructions of what they themselves should do, the attention is turned to "the Levites who are in your towns" (lit. "gates"). The function of the LD could be described as that of the change (i.e. switch) of the group about whom instructions are given. It eases the effort to process this switch about whom instructions are giving, and ensure that the audience process the information given to them well: "Do not neglect them, because they have no allotment or inheritance with you". If one considers how the audience is again reminded in Deut 14:29 that "...the Levities, because they have no allotment or inheritance with you", it may be argued that the speakers regarded it important to make certain that the audience keep this notion and its consequences for them in mind.

\section{Deut. 14:27 (uniquely identifiable)}

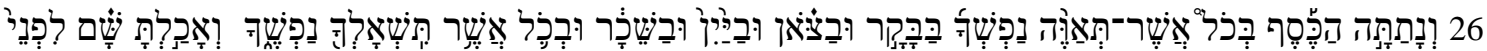

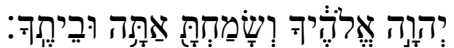

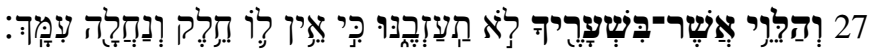

26 "spend the money for whatever you wish-oxen, sheep, wine, strong drink, or whatever you desire. And you shall eat there in the presence of the Lord your God, you and your household rejoicing together.

${ }^{27}$ As for the Levites resident in your towns, do not neglect them, because they have no allotment or inheritance with you." (NRSV)

\begin{tabular}{|c|c|}
\hline KJV & $\begin{array}{l}\text { And the Levite that is within thy gates; thou shalt not forsake him; for he hath } \\
\text { no part nor inheritance with thee. }\end{array}$ \\
\hline NKJV & $\begin{array}{l}\text { You shall not forsake the Levite who is within your gates, for he has no part } \\
\text { nor inheritance with you. }\end{array}$ \\
\hline DBV & $\begin{array}{l}\text { Die Leviete wat in jou dorpe is, jy mag hulle nie vergeet nie, want hulle het } \\
\text { geen aandeel of erfenisse saam met jou nie. [The Levites who are in your } \\
\text { towns, you may not forget them, for they have share or inheritances with you.] }\end{array}$ \\
\hline Elberf. & Und den Leviten, der in deinen Toren $<$ wohnt $>$, den sollst du nicht verlassen... \\
\hline NASB & Also you shall not neglect the Levite who is in your town... \\
\hline ESV & And you shall not neglect the Levite who is within your towns... \\
\hline NJPS & But do not neglect the Levite in your community... \\
\hline
\end{tabular}

\footnotetext{
${ }^{13}$ In the case of the BNV, it could be argued that the use of two sentences represents an attempt to enhance the processing effort (cf. Andrason 2016a).
} 


\begin{tabular}{|c|c|}
\hline NJB & Do not neglect the Levite living in your community... \\
\hline NIV & And do not neglect the Levites living in your towns... \\
\hline CEB & Only make sure not to neglect the Levites who are living in your cities... \\
\hline NBV & En vergeet daarbij de Levieten die bij u in de stad wonen niet... \\
\hline ISV & But you must not forget the descendant of Levi in your town... \\
\hline NET & As for the Levites in your villages, you must not ignore them, .... \\
\hline NLT & And do not neglect the Levites in your town... \\
\hline NLV & Moenie die Leviete in jou gemeenskap vergeet nie... \\
\hline BNV & Moenie die Leviete wat in jou omgewing woon, vergeet nie, ... \\
\hline GNB & Do not neglect the Levites who live in your towns; ... \\
\hline CEV & $\begin{array}{l}\text { And since people of the Levi tribe won't own any land for growing crops, } \\
\text { remember to ask the Levites to celebrate with you... }\end{array}$ \\
\hline Message & $\begin{array}{l}\text { Meanwhile, don't forget to take good care of the Levites who live in your } \\
\text { towns;... }\end{array}$ \\
\hline
\end{tabular}

The KJV, Elberf., DBV, NRSV and NET formally resemble the LD. The NASB, NJPS, CEB, NBV, Message and CEV suggest some type of shift. It is significant that many translations from all positions on the cline (NKJV, ESV, NJB, NIV, NLT, NLV, GNB) do not overtly try to resemble a LD here at all. ${ }^{14}$ The question that could be posed is: if the NET and Message on the FUE side of the continuum display a sensitivity for the function of the LD, why do so many versions on the FOE pole appear to "ignore" the construction?

\section{Example 3}

The speaker, the Lord, announces himself as Yahweh, the God of Jacob’s ancestors. The Lord activates an identifiable entity, i.e. the ground/land on which Jacob was lying, by means of a LD in order to serve as the topic of the promise that he announces to Jacob. It is significant that the subsequent clause commences with a fronted indirect object - "to you" (which also has a split coordinated element “and to your off-spring”).

\footnotetext{
${ }^{14}$ Of these translations, the following link vs. 27 with a paragraph that starts in vs. 22. (NKJV, Elberf.; NRSV, ESV; NJB, NIV, CEB, NBV, NLT, BNV, CEV). Only the DBV, NJPS, ISV and GNB distinguishes a new pararagraph that runs from vs. 27 to 29. The Message distinguishes two new sub-paragraphs, viz. 27 and 28-29. The NET and NLV treat vss. 22-29 as one paragraph. It is significant that not all translations that appear to "interpretively resemble" the LD, distinguish a new paragraph, e.g. the Elberf., NRSV and NET (cf. CEB and NBV which reflect some sort of shift from vs.22-26 to vs. 27). Only in the DBV a prototypical LD construction coincides with a new paragraph. In the NJPS and ISV some sort of shift "but" coincides with distinguishing a new paragraph. In the GNB a new paragraph is distiguished with a translation that does not overtly reflect any shift from $22-26$ to $27-29$.
} 
(3) Gen. 28.13 (uniquely identifiable)

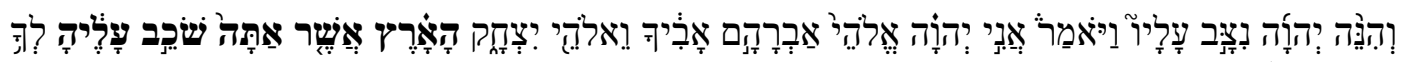

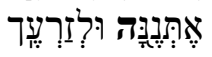

"Ek is die HERE, die God van jou voorvader Abraham, en die God van Isak.

Die grond waarop jy lê, aan jou en jou nageslag sal Ek dit gee / gee ek dit." (DBV)

"I am the LORD, the God of Abraham your father and the God of Isaac; the land on which you lie, to you and to your offspring I will give / I am giving it."15

\begin{tabular}{|c|c|}
\hline KJV & the land whereon thou liest, to thee will I give it, and to thy seed; \\
\hline NKJV & the land on which you lie I will give to you and your descendants. \\
\hline Elberf. & $\begin{array}{l}\text { das Land, auf dem du liegst, dir will ich es geben und deiner } \\
\text { Nachkommenschaft. }\end{array}$ \\
\hline NASB & the land on which you lie, I will give it to you and to your descendants. \\
\hline NRSV & the land on which you lie I will give to you and to your offspring; \\
\hline ESV & The land on which you lie I will give to you and to your offspring. \\
\hline NJPS & the ground on which you are lying I will assign to you and to your offspring. \\
\hline NJB & The ground on which you are lying I shall give to you and your descendants. \\
\hline NIV & I will give you and your descendants the land on which you are lying. \\
\hline CEB & I will give you and your descendants the land on which you are lying. \\
\hline NBV & Het land waarop je nu ligt te slapen zal ik aan jou en je nakomelingen geven. \\
\hline ISV & I'm giving you and your descendants the ground on which you're sleeping. \\
\hline NET & I will give you and your descendants the ground you are lying on. \\
\hline NLT & $\begin{array}{l}\text { The ground you are lying on belongs to you. I am giving it to you and your } \\
\text { descendants. }\end{array}$ \\
\hline NLV & Die grond waarop jy lê, gee Ek vir jou en jou nageslag. \\
\hline GNB & I will give to you and to your descendants this land on which you are lying. \\
\hline $\mathrm{CEV}$ & I will give to you and your family the land on which you are now sleeping. \\
\hline Message & $\begin{array}{l}\text { I'm giving the ground on which you are sleeping to you and to your } \\
\text { descendants. }\end{array}$ \\
\hline
\end{tabular}

${ }^{15}$ Cf Hamilton (1995: 237) "the ground on which you are stretched out, to you I will give it, and to your descendants." 
Most English translations do not overtly reflect the LD (16/20). Most on the formal equivalence pole of the continuum, do, however, commence with the dislocated constituent (NKJV, NRSV, ESV, NJPS, NJB). On the functional equivalence side of the continuum, the NBV and NLV also commence with the LD. The LD is only resumed in the matrix in the case of the KJV, DBV, Elberf. and NASB.

The NIV, CEB, ISV, NET and CEV do not reflect any overt clue to resemble the LD construction. The "this land" of GNB might be regarded as a trace of an attempt to reflect the LD. This also applies to the NLT's use of two sentences, as well as the Message's putting “the ground ...." before "to you and your descendants". However, the latter may also be an attempt to reflect the fronting of the indirect object of the matrix clause.

It appears then, that on the FOE side of the continuum, only the translations that are dedicated to word for word translation - and the DBV - maintain the LD. A few others on that side of the continuum, but only two others on the FUE side, acknowledge that a marked construction is concerned. In other words, most translations do not overtly reflect the LD.

Furthermore, only KJV, Elberf. and DBV, overtly try to reflect to function of the fronting in the matrix clause.

If one considers Gen. 28:13-19, it is apparent that the discourse topic of the paragraph is "the land on which Jacob was lying" - and the fact that God is giving it exclusively to him and his descendants, and that He intends to make certain that the land stays that of Jacob and his family. The latter nuance is only overtly indicated in the DBV, Elberf., NLT and perhaps the Message.

One gets the impression that what is considered "idiomatic" English played a role in the apparent lack of fully resembling the LD in the source text. In the light of the renderings of the NKJV, NRSV, ESV, NJPS, NJB, NBV and NLV, it may be argued that fronting in English is regarded as a construction that 'interpretively resembles' a LD construction in BH. This may demonstrate the (close) functional relationship between LD and Fronting (cf. Andrason and Visser 2016; Andrason 2016a\&b).

\section{Example 4}

The LD in this example forms part of what could be regarded as a type of list, viz. (1) "a nation and a company of nations" shall come from you; (2) and "kings" shall spring from you; (3) and "the land..." The first two members of the "list" are fronted subjects in the clauses in which they are used. The LD in vs. 12, activates another member of the list which is the "marked" object of the subsequent clause. The latter begins with a fronted indirect object (like in Example 3).

(4) Gen. 35:11-12 (uniquely identifiable)

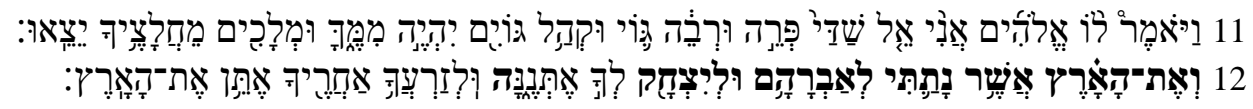

${ }^{11}$ God said to him, "I am God Shaddai: be fruitful and multiply; a nation and a company of nations shall come from you, and kings shall spring from you. 
${ }^{12}$ And, the land that I gave to Abraham and Isaac, to you I will give it, and

also to your off-spring after you I will give the land." (Own translation)

\begin{tabular}{|c|c|}
\hline KJV & $\begin{array}{l}\text { And the land which I gave Abraham and Isaac, to thee I will give it, and to } \\
\text { thy seed after thee will I give the land. }\end{array}$ \\
\hline NKJV & $\begin{array}{l}\text { The land which I gave Abraham and Isaac I give to you; and to your } \\
\text { descendants after you I give this land. }\end{array}$ \\
\hline \multirow[t]{2}{*}{ DBV } & $\begin{array}{l}\text { Die land wat Ek aan Abraham en aan Isak gegee het, } \\
\text { gee Ek aan jou; } \\
\text { ook aan jou nageslag ná jou } \\
\text { gee Ek die land (DBV). }\end{array}$ \\
\hline & $\begin{array}{l}\text { [The land that I gave to Abraham and Isaac, } \\
\text { give I to you } \\
\text { also to you off-spring after you } \\
\text { give I the land] }\end{array}$ \\
\hline Elberf. & $\begin{array}{l}\text { Und das Land, das ich Abraham und Isaak gegeben habe, dir will ich es } \\
\text { geben, und deinen Nachkommen nach dir will ich das Land geben, }\end{array}$ \\
\hline NASB & $\begin{array}{l}\text { The land which I gave to Abraham and Isaac, } \\
\text { I will give it to you, } \\
\text { And I will give the land to your descendants after you. }\end{array}$ \\
\hline NRSV & $\begin{array}{l}\text { The land that I gave to Abraham and Isaac I will give to you, and I will give } \\
\text { the land to your offspring after you. }\end{array}$ \\
\hline ESV & $\begin{array}{l}\text { The land that I gave to Abraham and Isaac I will give to you, and I will give } \\
\text { the land to your offspring after you. }\end{array}$ \\
\hline NJPS & $\begin{array}{l}\text { The land that I assigned to Abraham and Isaac } \\
\text { I assign to you; } \\
\text { And to your offspring to come will I assign the land. }\end{array}$ \\
\hline NJB & $\begin{array}{l}\text { The country which I gave to Abraham and Isaac, I now give to you; and this } \\
\text { country I shall give to your descendants after you, }\end{array}$ \\
\hline NIV & $\begin{array}{l}\text { The land that I gave to Abraham and Isaac I will give to you, and I will give } \\
\text { the land to your offspring after you, }\end{array}$ \\
\hline CEB & $\begin{array}{l}\text { The land I gave to Abraham and to Isaac, I give to you; and I will give the } \\
\text { land to your descendants after you, }\end{array}$ \\
\hline NBV & $\begin{array}{l}\text { Ik geef jou het land dat ik aan Abraham en aan Isaak heb gegeven; ook aan } \\
\text { je nakomelingen geef ik dit land, }\end{array}$ \\
\hline ISV & $\begin{array}{l}\text { Now as for the land } \\
\text { that I gave to Abraham and Isaac, } \\
\text { I'm giving it to you } \\
\text { and to your descendants who come after you. } \\
\text { I'm giving the land to you! }\end{array}$ \\
\hline
\end{tabular}




\begin{tabular}{|l|l|}
\hline NET & $\begin{array}{l}\text { The land I gave to Abraham and Isaac I will give to you. To your } \\
\text { descendants I will also give this land, }\end{array}$ \\
\hline NLT & $\begin{array}{l}\text { And I will give you the land I once gave to Abraham and Isaac. Yes, I will } \\
\text { give it to you and your descendants after you. }\end{array}$ \\
\hline NLV & $\begin{array}{l}\text { Hierdie land wat Ek vir Abraham en Isak gegee het, sal Ek vir jou en jou } \\
\text { nageslag gee, }\end{array}$ \\
\hline BNV & $\begin{array}{l}\text { Hierdie land wat Ek aan Abraham en aan Isak gegee het, sal Ek aan jou gee } \\
\text { en ná jou gee Ek dit aan jou nageslag, }\end{array}$ \\
\hline CEV & $\begin{array}{l}\text { I will give you the land which I gave to Abraham and to Isaac, and I will } \\
\text { also give it to your descendants after you, }\end{array}$ \\
\hline I will give you the land that I promised Abraham and Isaac, and it will \\
belong to your family forever,
\end{tabular}

Whether a list is involved here, may be contested. Only the KJV, Elberf. and NLT overtly translate the waw in vs. 12.

Most translations (KJV, DBV, Elberf, NASB, NJB, CEB, ISV, NLV, BNV) dislocate the LD by means of a comma, or they front it (NJKV, NRSV, ESV, NJPS, NIV, NET, Message). Only four resume the LD pronominally (KJV, Elberf., NASB and ISV). Three translations on the FUE pole do not overtly reflect any attempt to interpretively resemble the LD (NBV, GNB and CEV). The NLT tries to explicate the relationships involved.

From the above-mentioned comparison, it appears as if most translators did observe the LD and acknowledged the need to interpretively resemble it. However, one gets the impression that the grammatical acceptability of the English language would need to be strained if one would like to resemble the resumptive pronoun (see also example 4). The same can be said about the rendering of the fronted indirect object of the matrix clause. ${ }^{16}$

\section{Example 5}

A feature of this example is that the referent of the LD, i.e. the land which Abraham could see, is activated in the matrix clause (Gen. 13:14) of the י-clause which the LD introduces. The LD is then used to profile it in terms of its quantity, viz. "all” of it. Like in examples 3 and 4, the indirect object of the matrix clause is fronted for constituent focus, viz. "to you alone".

\footnotetext{
${ }^{16}$ From the translations above, the ISV on the FUE pole of the cline, provides a possible translation solution. Other possible translation solutions are the use of a comma or a dash, since they provide ortographic indications of a pause that make the processing of the LD easier.
} 
(5)

Gen. 13.14-15

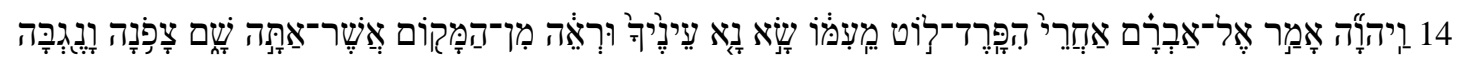

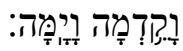

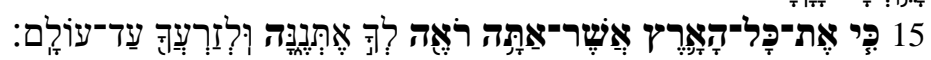

${ }^{14}$ The LORD said to Abram, after Lot had separated from him, "Raise your eyes now, and look from the place where you are, northward and southward and eastward and westward;

${ }^{15}$ want die hele land wat jy sien, vir jou sal Ek dit_gee en vir jou nageslag, vir altyd." (DBV)

15 "For all the land that you see, to you I will give it and to you offspring forever."

\begin{tabular}{|c|c|}
\hline KJV & $\begin{array}{l}\text { For all the land which thou seest, to thee will I give it, and to thy seed for } \\
\text { ever. }\end{array}$ \\
\hline NKJV & for all the land which you see I give to you and your descendants forever. \\
\hline Elberf. & $\begin{array}{l}\text { Denn das ganze Land, das du siehst, dir will ich es geben und deinen } \\
\text { Nachkommen für ewig. }\end{array}$ \\
\hline NASB & $\begin{array}{l}\text { for all the land which you see, I will give it to you and to your descendants } \\
\text { forever. }\end{array}$ \\
\hline NRSV & for all the land that you see I will give to you and to your offspring forever. \\
\hline ESV & for all the land that you see I will give to you and to your offspring forever. \\
\hline NJPS & for I give all the land that you see to you and your offspring forever. \\
\hline NJB & for all the land within sight I shall give to you and your descendants for ever, \\
\hline NIV & All the land that you see I will give to you and your offspring forever, \\
\hline CEB & because all the land that you see I give you and your descendants forever, \\
\hline NBV & Al het land dat je ziet geef ik aan jou en je nakomelingen, voor altijd, \\
\hline ISV & $\begin{array}{l}\text { because I'm going to give you and your descendants all of the land that you } \\
\text { see-forever! }\end{array}$ \\
\hline NET & I will give all the land that you see to you and your descendants forever, \\
\hline NLT & $\begin{array}{l}\text { I am giving all this land, as far as you can see, to you and your descendants } \\
\text { as a permanent possession, }\end{array}$ \\
\hline NLV & Hierdie land gaan Ek vir jou en jou nageslag as permanente eiendom gee. \\
\hline BNV & Die hele land wat jy sien, gee Ek vir altyd aan jou en jou nageslag. \\
\hline GNB & $\begin{array}{l}\text { I am going to give you and your descendants all the land that you see, and it } \\
\text { will be yours for ever, }\end{array}$ \\
\hline
\end{tabular}




\begin{tabular}{|l|l|}
\hline CEV & $\begin{array}{l}\text { I will give you and your family all the land you can see. It will be theirs } \\
\text { forever! }\end{array}$ \\
\hline Message & $\begin{array}{l}\text { Everything you see, the whole land spread out before you, I will give to you } \\
\text { and your children forever. }\end{array}$ \\
\hline
\end{tabular}

Most translations front the LD (NKJV, NRSV, ESV, NJB, NIV, CEB, NBV, NLV), dislocate it by means of a comma (BNV and Message), and even resume the dislocated constituent (KJV, DBV, Elberf., NASB). Exceptions to this include the NJPS, NET, NLT on the one hand, and the ISV, GNB and CEV on the other. The former putting the LD of the Hebrew text before the indirect object, and the latter putting it after the indirect object of their translations.

Only the DBV and Elberf. front the indirect object in the matrix clause, thus reflecting the source text.

If one considers vss. 16-17, it is clear that the quantified LD item "all of the land" is the discourse topic of God's speech to Abraham "walk around through the length and breadth of the land" (vs. 17a) - as well the notion "to you I give it" (vs 17b).

Like in example 4, most translations try to interpretively resemble the marked construction, albeit to a lesser degree by means of a comma. The same translations on the FOE pole of the continuum resume the LD (KJV, DBV, Elberf. and NASB). However, in example 5, slightly more translations on the FUE pole do not overtly resemble the LD (NET, NLT, ISV, GNB and $\mathrm{CEV}$ ). Remarkable is the rendering of the ISV - which lacks any overt resemblance of the LD. In example 4, it was the ISV that provides what I have regarded as a possible translation solution for the LD in that context of use.

Nevertheless, with respect to example 5, fronting (and to a lesser extent, the use of the comma) with no resumptive element in the subsequent clause, is regarded by the majority of the translations in our corpus to be the most appropriate way to resemble the LD in BH (cf. examples 3 and 4$)$.

\section{Example 6}

In this example, it can also be argued that a discourse active entity (in Gen. 28:20-21) is profiled by means of the LD in terms of its quantity. The speaker then makes a committed promise regarding the profiled quantity, i.e. "all that you give me".

(6) Gen. 28.22

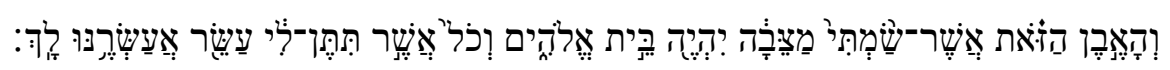

"dan sal hierdie klip wat ek as gedenkteken/ gedenksteen opgerig het, 'n huis van God wees. En alles wat U vir my gee, 'n tiende daarvan sal ek sekerlik vir U teruggee."

"then will this stone, which I have set up as a memorial, shall be a house of God; and all that you give me, I will surely give one-tenth of it to you." (DBV). 


\begin{tabular}{|c|c|}
\hline KJV & and of all that thou shalt give me I will surely give the tenth unto thee. \\
\hline NKJV & and of all that You give me I will surely give a tenth to You. \\
\hline Elberf. & und alles, was du mir geben wirst, werde ich dir treu verzehnten. \\
\hline NASB & and of all that You give me I will surely give a tenth to You. \\
\hline NRSV & and of all that you give me I will surely give one-tenth to you. \\
\hline ESV & And of all that you give me I will give a full tenth to you. \\
\hline NJPS & and of all that You give me, I will set aside a tithe for You. \\
\hline NJB & and I shall faithfully pay you a tenth part of everything you give me. \\
\hline NIV & and of all that you give me I will give you a tenth. \\
\hline CEB & and of everything you give me I will give a tenth back to you. \\
\hline NBV & en ik beloof dat ik u dan een tiende deel zal afstaan van alles wat u mij geeft. \\
\hline ISV & and I'll give you a tenth of everything that you give to me. \\
\hline NET & and I will surely give you back a tenth of everything you give me. \\
\hline NLT & and I will present to God a tenth of everything he gives me. \\
\hline NLV & en van alles wat $U$ vir my gee, sal ek vir U 'n tiende afstaan. \\
\hline BNV & en van alles wat U my gee, sal ek vir U 'n tiende gee. \\
\hline GNB & and I will give you a tenth of everything you give me. \\
\hline CEV & and I will give back to you a tenth of everything you give me. \\
\hline Message & And everything you give me, I'll return a tenth to you. \\
\hline
\end{tabular}

Most translations front the LD (KJV, NKJV, NRSV, NASB, ESV, NIV, CEB and Message), dislocate it by means of a comma (NJPS, NLV and BNV), or resume the fronted LD (DBV and Elberf.). A feature of the versions that front the LD (without or with a comma, is that they "accommodate" the resumption of the LD with a pronoun suffixed to the verb in the Hebrew by means of the notion "all of". The only exceptions are the Elberf. and the DBV. While the latter resumes the $\mathrm{LD}$, the former does not.

Quite a number of translations on the functional equivalent pole, do not overtly resemble the LD in any way (NJB, NBV, ISV, NET, NLT, GNB and CEV).

It appears that this is also an instance of LD in which it is not easy to resume the dislocated item in the matrix clause due to constraints particular to Germanic languages. The DBV is the only translation that does it, but uses a dash to render the Afrikaans in an idiomatic fashion. (See the suggestion in example 4 concerning the use of a dash to interpretively resemble a LD construction.) 
Most of the translations on the FUE pole, refrain from interpretively resembling the LD. The exception is, again, the Message. See also example 1, 2, 4 and 5.

\section{Example 7}

In this example, a discourse active entity "the woman" is dislocated to profile her in terms of the qualification of an aspect of her identity, viz. "whom you gave me". The crux of Adam's response to God's question: "Have you eaten from the tree of which I commanded you not to eat?" is then provided in the subsequent clause, viz. it is she/she is the one that/shé gave me from the tree's fruit and I ate of it.

(7) Gen. 3:12

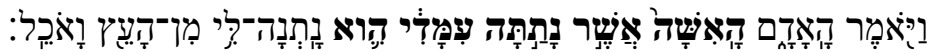

"Die vrou wat U my gegee het om by my te wees, sý het vir my van die boom se vrugte gegee, en ek het daarvan geëet." (DBV).

"The woman whom you gave to be with me, she gave me from the tree's fruit and I ate of it."

\begin{tabular}{|l|l|}
\hline KJV & $\begin{array}{l}\text { The woman whom thou gavest to be with me, she gave me of the tree, and I } \\
\text { did eat. }\end{array}$ \\
\hline NKJV & $\begin{array}{l}\text { The woman whom you gave to be with me, she gave me fruit from the tree, } \\
\text { and I ate. }\end{array}$ \\
\hline Elberf. & $\begin{array}{l}\text { Die Frau, die du mir zur Seite gegeben hast, sie gab mir von dem Baum, und } \\
\text { ich aß. }\end{array}$ \\
\hline NASB & $\begin{array}{l}\text { The woman whom You gave to be with me, she gave me from the tree, and I } \\
\text { ate. }\end{array}$ \\
\hline NRSV & $\begin{array}{l}\text { The woman whom you gave to be with me, she gave me fruit from the tree, } \\
\text { and I ate. }\end{array}$ \\
\hline ESV & $\begin{array}{l}\text { The woman whom you gave to be with me, she gave me fruit of the tree, and } \\
\text { I ate. }\end{array}$ \\
\hline NJPS & $\begin{array}{l}\text { The woman You put at my side-she gave me of the tree, and I ate. } \\
\text { I was the woman you put with me; she gave me some fruit from the tree, and }\end{array}$ \\
\hline NJB & $\begin{array}{l}\text { The woman you put here with me-she gave me some fruit from the tree, } \\
\text { and I ate it. }\end{array}$ \\
\hline NIV & $\begin{array}{l}\text { The woman you gave me, she gave me some fruit from the tree, and I ate. } \\
\text { De vrouw die u hebt gemaakt om mij terzijde te staan, heeft mij vruchten van } \\
\text { de boom gegeven en toen heb ik ervan gegeten. }\end{array}$ \\
\hline CEB & NBV
\end{tabular}




\begin{tabular}{|l|l|}
\hline ISV & $\begin{array}{l}\text { The woman whom you provided for me gave me fruit from the tree, and I ate } \\
\text { some of it. }\end{array}$ \\
\hline NET & $\begin{array}{l}\text { The woman whom you gave me, she gave me some fruit from the tree and I } \\
\text { ate it. }\end{array}$ \\
\hline NLT & $\begin{array}{l}\text { It was the woman you gave me who gave me the fruit, and I ate it. } \\
\text { "Ja," erken die mens, "maar dit was die vrou wat U my gegee het om by my } \\
\text { te wees wat die vrugte vir my aangebied het, en toe het ek daarvan geëet." }\end{array}$ \\
\hline BNV & $\begin{array}{l}\text { Die vrou wat U my gegee het om my by te staan, sy het vir my van die boom } \\
\text { se vrugte gegee, en ek het geëet. }\end{array}$ \\
\hline GNB & $\begin{array}{l}\text { The woman you put here with me gave me the fruit, and I ate it. } \\
\text { of the fruit, and I ate it." }\end{array}$ \\
\hline CEV & $\begin{array}{l}\text { The Woman you gave me as a companion, she gave me fruit from the tree, } \\
\text { and, yes, I ate it. }\end{array}$ \\
\hline Message
\end{tabular}

Most of the translations (13/20) overtly resemble the LD constituent (KJV, NKJV, DBV, NRSV, Elberf., NASB, ESV, NJPS, NIV, CEB, NET, BNV and Message). Some read the construction as if it is focus announcing (NJB and CEV), and others as if it is a constituent focus construction (NLT). Some appear not to reflect the LD construction at all (ISV and GNB). The NLV explicates the construction, while the NBV distinguishes the LD constituent by means of a comma, but does not resume the LD in the matrix clause with a pronominal element.

It could be argued that the use of the LD represents a diplomatic rhetorical strategy of first announcing the qualities ("whom you gave me to be with me"), and then identifying-by means of a fronted subject-the guilty party. This diplomatic strategy is missing in the NJB, CEV, NLT and NLV.

In this example, translations typically do not have difficulties interpretively resembling the LD construction. Yet, the question as to how to render the constituent focus, marked by the fronted subject, appears to be more problematic. The same applies to example 8 below.

\section{Example 8}

In this example, the reference to a discourse active entity "God" is dislocated in order to profile him in terms of the qualification of an aspect of his identity, viz. "The Lord, the God of heaven, who took me from my father's house and from the land of my birth, and who made me a promise and confirmed it with an oath, 'To your offspring I give this land,'”. The crux of the promise to Abraham is provided, viz. this God himself will ..... 
(8) Gen. 24:7

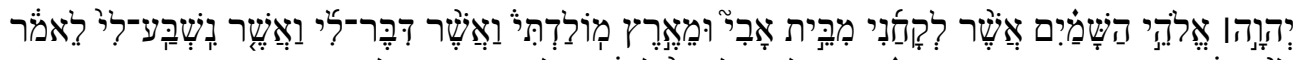

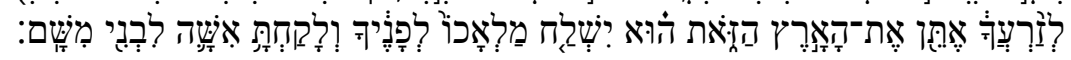

"Die HERE, die God van die hemel, wat my uit my ouerhuis en my geboorteland geneem het, en wat aan my 'n belofte gemaak en dit met ' $n$ eed bevestig het, "Aan jou nageslag gee Ek hierdie land, Hy self sal sy engel voor jou uitstuur sodat jy 'n vrou vir my seun van daar af kan bring." (DBV)

"The LORD, the God of heaven, who took me from my father's house and from the land of my birth, and who made me a promise and confirmed it with an oath, 'To your offspring I give this land,' He himself will send his angel before you, and so that you can bring a wife for my son from there."

\begin{tabular}{|l|l|}
\hline KJV & $\begin{array}{l}\text { The Lord God of heaven, which took me from my father's house, and from } \\
\text { the land of my kindred, and which spake unto me, and that sware unto me, } \\
\text { saying, Unto thy seed will I give this land; he shall send his angel before } \\
\text { thee, and thou shalt take a wife unto my son from thence. }\end{array}$ \\
\hline NKJV & $\begin{array}{l}\text { The Lord God of heaven, who took me from my father's house and from the } \\
\text { land of my family, and who spoke to me and swore to me, saying, 'To your } \\
\text { descendants I give this land,' He will send His angel before you, and you } \\
\text { shall take a wife for my son from there. }\end{array}$ \\
\hline Elberf. & $\begin{array}{l}\text { Der HERR, der Gott des Himmels, der mich aus dem Haus meines Vaters } \\
\text { und aus dem Land meiner Verwandtschaft genommen und der zu mir geredet } \\
\text { und der mir dies geschworen hat: Deinen Nachkommen will ich dieses Land } \\
\text { geben, der wird seinen Engel vor dir hersenden, daß du eine Frau für meinen } \\
\text { Sohn von dort holen kannst. }\end{array}$ \\
\hline NASB & $\begin{array}{l}\text { The Lord God of heaven, who brought me from my father's house and from } \\
\text { my family's land, who spoke to me and promised me 'I will give this land to } \\
\text { your descendants,' will send his angel ahead of you, and you are to acquire } \\
\text { a wife for my son from there. }\end{array}$ \\
\hline NRSV & $\begin{array}{l}\text { The Lord, the God of heaven, who took me from my father's house and from } \\
\text { the land of my birth, and who spoke to me and swore to me, 'To your } \\
\text { offspring I will give this land,' he will send his angel before you, and you } \\
\text { shall take a wife for my son from there. }\end{array}$ \\
\hline $\begin{array}{l}\text { The Lord, the God of heaven, who took me from my father's house and from } \\
\text { the land of my kindred, and who spoke to me and swore to me, 'To your } \\
\text { offspring I will give this land,' he will send his angel before you, and you } \\
\text { shall take a wife for my son from there. }\end{array}$ \\
\hline ESV
\end{tabular}




\begin{tabular}{|c|c|}
\hline NJPS & $\begin{array}{l}\text { The Lord, the God of heaven, who took me from my father's house and from } \\
\text { my native land, who promised me on oath, saying, 'I will assign this land to } \\
\text { your offspring'-He will send His angel before you, and you will get a wife } \\
\text { for my son from there. }\end{array}$ \\
\hline NJB & $\begin{array}{l}\text { Yahweh, God of heaven and God of earth, who took me from my father's } \\
\text { home, and from the land of my kinsfolk, and who promised me on oath, "I } \\
\text { shall give this country to your descendants"-he will now send his angel } \\
\text { ahead of you, so that you can get a wife for my son from there. }\end{array}$ \\
\hline NIV & $\begin{array}{l}\text { "The Lord, the God of heaven, who brought me out of my father's household } \\
\text { and my native land and who spoke to me and promised me on oath, saying, } \\
\text { 'To your offspring }{ }^{p} \text { I will give this land'-he will send his angel before you } \\
\text { so that you can get a wife for my son from there. }\end{array}$ \\
\hline CEB & $\begin{array}{l}\text { The Lord, God of heaven-who took me from my father's household and } \\
\text { from my family's land, who spoke with me and who gave me his word, } \\
\text { saying, 'I will give this land to your descendants'-he will send his } \\
\text { messenger in front of you, and you will find a wife for my son there. }\end{array}$ \\
\hline NBV & $\begin{array}{l}\text { De heer, de God van de hemel, die mij heeft opgedragen weg te gaan bij mijn } \\
\text { naaste verwanten en mijn geboorteland te verlaten en die mij onder ede } \\
\text { beloofd heeft dat hij dit land hier aan mijn nakomelingen zal geven, hij zal } \\
\text { zijn engel voor je uit sturen, zodat je daar een vrouw voor mijn zoon zult } \\
\text { vinden. }\end{array}$ \\
\hline ISV & $\begin{array}{l}\text { The Lord God of heaven, who brought me from my father's house and from } \\
\text { my family's land, who spoke to me and promised me 'I will give this land to } \\
\text { your descendants,' will send his angel ahead of you, and you are to acquire } \\
\text { a wife for my son from there. }\end{array}$ \\
\hline NET & $\begin{array}{l}\text { "The LORD, the God of heaven, who took me from my father's house and the } \\
\text { land of my relatives, promised me with a solemn oath, 'To your descendants } \\
\text { I will give this land.' He will send his angel before you so that you may find } \\
\text { a wife for my son from there. }\end{array}$ \\
\hline NLT & $\begin{array}{l}\text { For the LORD, the God of heaven, who took me from my father's house and } \\
\text { my native land, solemnly promised to give this land to my descendants. He } \\
\text { will send his angel ahead of you, and he will see to it that you find a wife } \\
\text { there for my son. }\end{array}$ \\
\hline NLV & $\begin{array}{l}\text { Die HERE, die God van die hemel wat my uit my pa se huis en my } \\
\text { geboorteland geroep het, het met 'n eed belowe om hierdie land aan my } \\
\text { nageslag te gee. Hy sal sy engel voor jou uitstuur en sorg dat jy daar 'n } \\
\text { meisie kry wat met my seun sal trou. }\end{array}$ \\
\hline
\end{tabular}




\begin{tabular}{|l|l|}
\hline BNV & $\begin{array}{l}\text { Die Here die God van die hemel het my weggevat uit my familie, uit die } \\
\text { werreld waar ek gebore is, en my met 'n eed beloof: 'Ek gee hierdie land } \\
\text { waar jy nou is, aan jou nageslag.' Die Here sal sy engel voor jou uit stuur } \\
\text { sodat jy vir my seun 'n vrou van my land af sal kan bring. }\end{array}$ \\
\hline GNB & $\begin{array}{l}\text { The Lord, the God of heaven, brought me from the home of my father and } \\
\text { from the land of my relatives, and he solemnly promised me that he would } \\
\text { give this land to my descendants. He will send his angel before you, so that } \\
\text { you can get a wife there for my son. }\end{array}$ \\
\hline Message & $\begin{array}{l}\text { The Lord who rules heaven brought me here from the land where I was born } \\
\text { and promised that he would give this land to my descendants forever. When } \\
\text { you go back there, the Lord will send his angel ahead of you to help you } \\
\text { find a wife for my son. }\end{array}$ \\
\hline $\begin{array}{l}\text { God, the God of Heaven, took me from the home of my father and from the } \\
\text { country of my birth and spoke to me in solemn promise, 'I'm giving this land } \\
\text { to your descendants.' This God will send his angel ahead of you to get a } \\
\text { wife for my son. }\end{array}$ \\
\hline
\end{tabular}

Most translations on the formal side of the continuum treat the 'long' LD item as a dislocated entity, using either a comma (KJV, NKJV, DBV, NRSV, Elberf., ESV, NBV) or a dash (NJPS, NJB, NIV, CEB). Although the NASB and the ISV do use a comma, the LD constituent is not resumed pronominally in the matrix clause. All the translations on the functional equivalent of the continuum make the LD item one sentence, and the matrix clause, a second sentence (NET, NLT, NLV, BNV, GNB, CEV and the Message). The BNV relexicalizes the LD, while the Message "adds" the near demonstrative "this" to relexicalized subject.

Translations on the FUE pole are true to their typical translation brief of providing translations that are not difficult to read. Most of them therefore turn the long LD + its matrix into two separate sentences. Such a two-sentence structure would correspond to the (pre-)intial stage of the grammaticalization of $\mathrm{LD}$, where the referent is (re)activated in the prevous utterance and resumed and functionally specified in the subsequent utterance (cf. Andrason and Visser 2016).

In the light of what emerges from the comparison of the LD + clause in examples 7 and 8, it is apparent that most translations struggle to overtly resemble the LD when it is resumed in the matrix clause as the fronted subject of that clause. This is also the case when the resumption of the LD that is fronted in the matrix clause is a non-subject constituent, cf. examples 3-5.

\section{Example 9}

In Gen. 2, God gave humans instructions concerning what they are allowed to eat in the garden. He first states that from all the trees in the garden, they may eat as much as they like. Then He dislocates the reference to one of the trees in order to profile it in terms of its identity, namely, the tree of knowledge of good and evil, and continues: "you may not eat from it". 
(9) Gen. 2:16-17

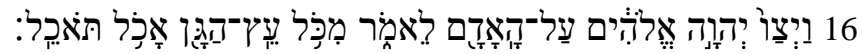

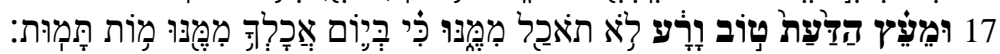

${ }^{16}$ Die HERE God het toe die mens beveel: "Van al die bome van die tuin, mag jy genoeg eet,

${ }^{17}$ maar van die boom van die kennis van goed en kwaad, jy mag daarvan ni eet nie ..." (DBV)

16 "And the LORD God commanded the man, "From all the trees in the garden, you may eat as much as you like / enough.

${ }^{17}$ but from the tree of the knowledge of good and evil, you may not eat from it..."

\begin{tabular}{|c|c|}
\hline KJV & $\begin{array}{l}{ }^{16} \text { And the LORD God commanded the man, saying, Of every tree of the garden } \\
\text { thou mayest freely eat: }{ }^{17} \text { But of the tree of the knowledge of good and evil, } \\
\text { thou shalt not eat of it: for in the day that thou eatest thereof thou shalt surely } \\
\text { die. }\end{array}$ \\
\hline NKJV & $\begin{array}{l}{ }^{16} \text { And the LORD God commanded the man, saying, "Of every tree of the } \\
\text { garden you may freely eat; }{ }^{17} \text { but of the tree of the knowledge of good and evil } \\
\text { you shall not eat, for in the day that you eat of it you shall surely die." }\end{array}$ \\
\hline NRSV & $\begin{array}{l}{ }^{16} \text { And the Lord God commanded the man, "You may freely eat of every tree } \\
\text { of the garden; }{ }^{17} \text { but of the tree of the knowledge of good and evil you shall not } \\
\text { eat, ... }\end{array}$ \\
\hline Elberf. & $\begin{array}{l}{ }^{16} \text { Und Gott, der HERR, gebot dem Menschen und sprach: Von jedem Baum } \\
\text { des Gartens darfst du essen; }{ }^{17} \text { aber vom Baum der Erkenntnis des Guten und } \\
\text { Bösen, davon darfst du nicht essen; ... }\end{array}$ \\
\hline NASB & but from the tree of the knowledge of good and evil you shall not eat, ... \\
\hline ESV & but of the tree of the knowledge of good and evil you shall not eat, ... \\
\hline NJPS & but as for the tree of knowledge of good and bad, you must not eat of it; ... \\
\hline NJB & But of the tree of the knowledge of good and evil you are not to eat; ... \\
\hline NIV & but you must not eat from the tree of the knowledge of good and evil, ... \\
\hline CEB & but don't eat from the tree of the knowledge of good and evil, ... \\
\hline NBV & maar niet van de boom van de kennis van goed en kwaad; ... \\
\hline ISV & but you are not to eat from the tree of the knowledge of good and evi, ... \\
\hline NET & but you must not eat from the tree of the knowledge of good and evil, ... \\
\hline NLT & except the tree of the knowledge of good and evil,... \\
\hline NLV & behalwe van die boom van alle kennis. \\
\hline BNV & maar van die boom van alle kennis mag jy nie eet nie. \\
\hline
\end{tabular}




\begin{tabular}{|c|c|}
\hline GNB & except the tree that gives knowledge of what is good and what is bad. \\
\hline $\mathrm{CEV}$ & $\begin{array}{l}\text { except the one that has the power to let you know the difference between right } \\
\text { and wrong. }\end{array}$ \\
\hline Message & except from the Tree-of-Knowledge-of-Good-and-Evil. Don't eat from it. \\
\hline
\end{tabular}

The NKJV, NRSV, NASB, ESV, NJB and BNV front the LD items (without any resumptive or comma). The NIV, CEB, ISV, NET do not by any means overtly resemble the LD. The NBV, NLT, NLV, GNB and CEV interprets the LD to overtly marking an exception.

The KJV, Elberf., NJPS and DBV interpretively resemble the LD. The DBV uses a dash in order to resume the pronoun later in the sentence. The Message may also be regarded as an attempt to resemble the $\mathrm{LD}$.

This use of the LD construction in Biblical Hebrew appears to be difficult to resemble formally in Germanic languages. This is most probably the reason why many of the FOE translations (6/20) merely front the LD constituent, while others to the "middle" of the continuum do not try to overtly resemble the construction, and those on the FUE pole try to resemble the essence of the semantics involved. The Message is surprising in that it tries to interpretively resemble the function of the LD by the use of a new form. i.e. one which corresponds to an extent to the (pre-)intial stage of the grammaticalization of LD. The referent to be excluded is activated in an utterance $A$ and resumed and functionally specified in the subsequent utterance B (cf. also example 8 and Andrason and Visser 2016).

\section{Example 10}

Example 10 could be regarded as an untypical instance of left-dislocation. A discourse active entity, Silla, is reactivated in order to profile her with respect to an activity that Lamech's other wife, Adah, already had performed, i.e. to give birth to a child.

Gen. 4.22

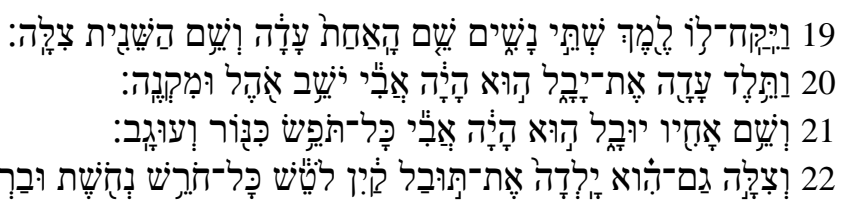

${ }^{19}$ Lamech took two wives; the name of the one was Adah, and the name of the other Zillah. ${ }^{20}$ Adah bore Jabal; he was the ancestor of those who live in tents and have livestock. ${ }^{21}$ His brother's name was Jubal; he was the ancestor of all those who play the lyre and pipe. (NRSV)

${ }^{22}$ En Silla, ook sy het geboorte gegee, aan Tubal-Kain. (DBV).

${ }^{22}$ And Zilla, she too gave birth, to Tubal-Cain. ... 


\begin{tabular}{|l|l|}
\hline KJV & And Zillah, she also bare Tubal-cain, ... \\
\hline NJKV & And as for Zillah, she also bore Tubal-Cain, ... \\
\hline Elberf. & Und Zilla, auch sie gebar <, und zwar > den Tubal-Kain, ... \\
\hline NASB & As for Zillah, she also gave birth to Tubal-cain, ... \\
\hline NRSV & Zillah bore Tubal-cain, .... \\
\hline ESV & Zillah also bore Tubal-cain; .... \\
\hline NJPS & As for Zillah, she bore Tubal-cain, ... \\
\hline NJB & As for Zillah, she gave birth to Tubal-Cain:... \\
\hline NIV & Zillah also had a son, Tubal-Cain, .... \\
\hline CEB & Zillah also gave birth to Tubal-cain, ... \\
\hline NBV & Ook Silla bracht een zoon ter wereld, Tubal-Kaïn; ... \\
\hline ISV & Zillah gave birth to Tubal-cain, ... \\
\hline NET & Now Zillah also gave birth to Tubal-Cain, ... \\
\hline NLT & Lamech’s other wife, Zillah, gave birth to a son named Tubal-cain. \\
\hline NLV & Tubal-Kain was die seun van Silla. \\
\hline BNV & Silla weer het vir Tubal-Kain in die wêreld gebring, ... \\
\hline GNB & Zillah gave birth to Tubal Cain, ... \\
\hline CEV & Lamech and Zillah had a son named Tubal Cain ... \\
\hline Message & Zillah gave birth to Tubal-Cain, ... \\
\hline
\end{tabular}

A LD is lexically distinguished by the NKJV, NASB, NJPS, NJB and by means of a comma in the KJV, Elberf., NLT and DBV. The NET Bible's "now” may also be attempt to resemble the LD. The scope of the focus particle aֵ , "Zillah", however, is seldom identified correctly. Cf. NKJV, NASB, NJPS, NJB, NET, NLT - in contrast to the Elberf. and DBV. The NIV, NBV and BNV identify the scope correctly, but do not overtly distinguish a LD.

The ESV and CEB do not overtly distinguish a LD, nor represent the scope of a correctly. Furthermore, many translations on the FUE pole of the continuum also fail to overtly interpretively resemble the LD or the focus particle, viz. ISV, NLT, NLV, GNB, CEV and the Message. Surprisingly, the NRSV is also part of this group.

If one considers the results of this comparison, it appears that translations at the FOE pole have found it easier to interpretively resemple an overt LD in Gen 4:22, than to identify the scope of the focus particle corretly. Translations on the FUA pole tend to fail to adequately resemble both the LD and the scope of the focus particle. It may be argued that the adequate resemblance 
of these communicative clues could have had enhanced the ease of processing information of the discourse paragraph for the target language audiences of those "easy to read" translations.

\section{Summary}

The empirical data, even though limited, confirmed the three hypotheses which I set out to investigate:

Firstly, in general, translations on the FOE pole tend to interpretively resemble LD constructions. If the LD tends to be very prototypical (e.g. example 1), this tendency is displayed even by some translations towards the FUE pole.

Secondly, however, even in those instances, translations on the FUE pole typically do not try to interpretively resemble the construction. In these cases, it could be argued that they are not serving the very goal they want to accomplish—viz, to provide readers with a translation that is easy to read and process.

Thirdly, the structure of English, Afrikaans and Dutch-in contrast to German-often appears to require a construal that does not formally reflect the pronominal resumption of the LD constituent in the matrix clause. In these languages, LD is often translated by fronting the dislocated constituent, and often a pause following the fronted constituent is signalled by way of a comma. Moreover, this observation corresponds to findings from other papers in the present volume: (i) Resumption, for example, is not always the primary distinctive feature of LD construction. A tonal pause between the LD and its matrix clause may also suffice (see Andrason 2016a and Khan 2016). (ii) Some functions of fronting and dislocation constructions overlap and there are historical linguistic reasons for this state of affairs (see Andrason 2016a and Khan 2016). Furthermore, pronominal resumption in the matrix clause may, in some languages, even be impermissible (see Andrason 2016b).

It was also found that 1) translations at all levels of the cline often struggle to interpretively resemble the semantic and pragmatic function of a fronted constituent in the matrix clause - in particular if the subject of the clause is fronted. The use of a dash after the dislocated constituent appears to be a possible strategy to address this translation problem; 2) translations that are closer to the FOE pole, as well as those that are in the middle of continuum, often appear to "gloss" over some less prototypical instances of the LD and/or fine nuanced distinctions; and 3) The Message (at the extreme FUE pole) often interprets (and interpretively resembles) the sense of a LD in an innovative manner.

\section{References}

Andrason, A. 2016a. Left Dislocation in Arabic: The complexity of form and meaning. Stellenbosch Papers in Linguistics Plus 50. 111-138.

Andrason, A. 2016b. To resume or not to resume: Some remarks on 'resumption' in left dislocation constructions in Polish, and its relevance for Biblical Hebrew. Stellenbosch Papers in Linguistics Plus 50. 185-199. 
Andrason, A. and M.W. Visser. 2016. The mosaic evolution of Left Dislocation in Xhosa. Stellenbosch Papers in Lingusitics Plus 50. 139-158.

BDV. forthcoming. Die Bybel: 'n Direkte Vertaling, Cape Town: Bible Society of South Africa. BNV. 1983. Die Bybel: Nuwe Vertaling, Cape Town: Bible Society of South Africa.

Carson, D. A. 1993. New Bible Translations: An Assessment and Prospect. In H. C. Kee (Ed.) The Bible in the Twenty-First Century. New York: American Bible Society. pp. 37-67.

CEB. 2011. Common English Bible, Nashville: TN: The Common English Bible.

CEV. 1997. The Contemporary English Version, Nashville: Thomas Nelson.

De Waard, J. and E. A. Nida. 1987. From One Language to Another. Functional Equivalence in Bible Translating. Nashville: Thomas Nelson.

Elberfelder. 1985. Die Bibel. Elberfelder ÜBersetzung, revidierte Fassung. Wuppertal: R. Brockhaus Verlag.

ESV. 2007. The Holy Bible English Standard Version, Wheaton, IL: Good News Publishers.

Geeraerts, D. 2010. Theories of Lexical Semantics, Oxford: Oxford University Press.

GNB. 1992. The Holy Bible: The Good News Translation (2 ${ }^{\text {nd }}$ edition). New York: American Bible Society.

Gutt, E.-A. 1991. Translation and Relevance: Cognition and Context, Oxford: Blackwell.

Gutt, E. A. 2000. Translation and Relevance. Cognition and Context ( $2^{\text {nd }}$ edition). Manchester \& Boston: St Jerome.

Hamilton, V. P. 1995. The Book of Genesis, Chapters 18-50, Grand Rapids: Eerdmans.

ISV 2011. International Standard Version, Yorba Linda, CA: ISV Foundation.

Khan, G. 2016. Left Dislocation in North-Eastern Neo-Aramaic Dialects. Stellenbosch Papers in Linguistics Plus 50. 91-110.

KJV. 1900. The Holy Bible: King James Version. (Electronic Edition of the 1900 Authorized Version.). Bellingham, WA: Logos Research Systems, Inc.

Metzer, B. M. 2001. The Bible in Translation: Ancient and English Versions, Grand Rapids: Baker Academic.

Mojola, A. O. and Wendland E., 2003. Scripture translation in the era of translation studies. In T. Wilt (Ed.), Bible Translation: Frames and Reference. Manchester: St. Jerome. pp. 1-26. 
NASB. 1995. New American Standard Bible, LaHabra, CA: The Lockman Foundation.

NBV. 2004. De Nieuwe Bijbelvertaling, Haarlem: Dutch Bible Society.

NET. 2005. The Net Bible, New English Translation, www.netbible.com: Biblical Studies Press.

Nida, E. A. and C. R. Taber. 1969. The Theory and Practice of Translation, Leiden: Brill.

NIV. 2011. The Holy Bible: New International Version, Grand Rapids: Zondervan.

NJB. 1985. The New Jerusalem Bible, New York: Doubleday.

NJPS. 1997 (electronic edition of 1985 version). Tanach: The Holy Scriptures, Philadelphia: Jewish Publication Society.

NKJV. 1982. The New King James Version. Nashville: Thomas Nelson.

NLT. 2007. Holy Bible: New Living Translation., Carol Stream. IL.: Tyndale Publishing House.

NLV. 2006. Die Bybel, Nuwe Lewende Vertaling, Vereeniging: Christelike Uitgewersmaatskappy.

NRSV. 1989. The Holy Bible: New Revised Standard Version, Nashville: Thomas Nelson.

Peterson, E. H. 2002. The Message: The Bible in Contemporary Language, Colorado Springs: NavPress.

Pym, A. 2010. Exploring Translation Theories, New York: Routledge.

Sperber, D. and D. Wilson. 1986. Relevance: Communication and Cognition, Oxford: Blackwell.

Van der Merwe, C.H.J. 1999. 'n Konkordante vertaling van die Bybel in Afrikaans. In hoegenaamd verantwoorDBVar, en hoe sal dit lyk? Nederduits Gereformeerde Teologiese Tydskrif 40(3-4). 293-306.

Van der Merwe, C. H. J. 2012. 'The Bible in Afrikaans. A Direct Translation - a New Type of Church Bible', Hervormde Teologiese Studies 68(1). Art. \#1204, 1-8.

http://dx.doi.org/10.4102/hts.v68i1.1204.

Van der Merwe, C. H. J. 2014. Direkte Vertaling Van Die Bybel as Antieke Teks: Net 'n Nuwe Benaming Vir'n Stokkerige Woordelikse Vertaling?. LitNet Akademies 11(3). Dec 2014.

Westbury, J. 2016. A Functional Profile of Left Dislocation in Biblical Hebrew. Stellenbosch Papers in Linguistics Plus 50. 65-90.

Wilt, T. A. 2003. Translation and Communication. In T. Wilt (Ed.) Bible Translation: Frames of Reference. Manchester: St. Jerome. pp. 27-80. 